Tavistock Clinic for Functional Nerve Cases, 51, Tavistock Square, W.C. I.A course of ten lectures on the Treatment of Functional Nerve Disease will be given at the Tavistock Clinic on Tuesdays, beginning Mlay 5, 1925, at 5.30 p.m.

H. Crichton-Miller, M.A., M.D., May 5, Psycho-physical Interaction; June 2, Freud; June 9, Adler and Jung; June 16 , Regression.

S. Roodhouse Gloyne, M.D. ; May I2, Toxæmia ; May 19, Toxæmia (contd.) ; May 26, The Endocrine Glands.

J. R. Rees, M.A., M.D.; June 23, Physical Methods of Treatment ; June 30, Analytical Methods; July 7, Analytical Methods (contd.).

Fee for the course : Medical practitioners, $£_{2} 2 s$.; medical students, $€ 1$ is. Single tickets, $5 s$. Tickets for the course to be obtained in advance from the Hon. Lecture Secretary at the Clinic.

The National Hospital for the Paralysed and Epileptic, Queen's Square, Bloomsbury, W.C. I. - Syllabus of Post-Graduate Course, May 4 to June 26, 1925.

The Course will consist of the following subjects: (I) Out-patient Clinics, Mondays, Tuesdays, Thursdays and Fridays, 2 p.m.; (2) Clinical Lectures and Demonstrations, Mondays, Tuesdays, Thursdays and Fridays, 3.30 p.m.; (3) Lectures on the Anatomy and Physiology of the Nervous System (if sufficient applicants), Tuesdays and Thursdays, 12 noon ; (4) Lectures on the Pathology of the Nervous System, Mondays, 12 noon ; (5) Clinical Demonstrations on Methods of Examination (if sufficient applicants), Tuesdays and Fridays, ro a.m.

For further information apply to J. G. Greesfield, Dean of Medical School.

\title{
THE MENTAL PATIENT AS HE FEELS HiMSELF.
}

I BELIEve, from my own experience, and from what $I$ have seen and heard of the experiences of other people who have suffered a mental or nervous breakdown, that there are two sets of signs which precede the illness. If the body is weaker than the mind, the body will give way first ; but in every case there will be physical signs as well as mental signs of nervous failure. Obstinate constipation, exhaustion and bodily heat often precede insomnia and loss of memory; but too often the sufferer does not pay any attention to these symptoms, merely thinking that he must be a little bit run down, whereas long-continued worry, work, or lack of fresh air and proper nourishment may be telling desperately upon the individual at last.

In my own case the physical symptoms which I have described were present. especially the exhaustion and bodily heat, which I found almost unendurable. The mental symptoms only occurred upon the very eve of my losing touch with reality. I was able to do my literary work quite well, that very evening; and yet a strangely abnormal occurrence rather frightened me. I was translating De Maupassant-the story of the man who is on the threshold of insanity, and who, one night, finds himself lost in Paris, and goes mad with terror. The story did not affect me, as I do my work without letting it remain with me afterwards; but when I left my desk in the immense reading-room of the British Museum I was unable to find it again, or to remember where $I$ had been sitting. Little did I think that the fate of the man in the story I had translated was to be mine also!

The borderland state, in which I then was, is a very strange one, in which reality and unreality are strangely mixed. I did not once think that anything was wrong with me, only that something was very wrong with other people. Phobias and delusions crowded in upon one. Above all, one's thoughts and dreams are real, and all else seems remote and artificial. Then, paradoxical as it may sound, there is a kind of rare sanity in insanity. For if sane, one is sensitive to impressions, one is doubly sensitive to them when intellectual checks and reasoning inhibitions are absent. The whole universe is, as it were, inverted, and instinct rules supreme ; and one reacts very strongly to those who are about one-almost as if one could see into their very souls. Pagan people, of course, respect the insane, believing that they are living in another world; and many Christian people have a religious theory of insanity. To a certain extent I sympathize with this, though it would be obvious folly for me to decry the splendid services which medical science has rendered to humanity. Suffice it to say, therefore, that the insane mind is primitive and child-like, and subject to receive strong and direct impressions. 
With regard to the treatment of the mentally afflicted, I think that before being certified a patient should be treated, and not sent to an asylum unless he is a bad case. It is terrible to send a young person to wake up in a lunatic asylum, to be branded for life for that which is often the fault of others, or a mere nervous disturbance which may be all over in ten days. That in itself is enough to cause a permanent deterioration of the brain. There should be certainly a half-way house between the asylum and a patient's own home.

In a letter to the Nursing Mirror last October I highly praised the mental nurse. I think, however, that she makes mistakes which could be remedied. With but a little effort of the imagination, she could place herself in her patient's place, and feel as he feels-lonely, terrified, weak, ashamed of his weakness, humiliated by the memory of his breakdown and the shock that it caused to others. She could soothe and cheer, be silent in the corridors at night-not leave him alone in the cold and dark, to get well or to get worse, or to die.

Suggestion, experiment or psycho-analysis is absolutely and obviously pernicious, for the mind is sick and defenceless, and too weak to be able to resist by reason, or right instinct.

A mental patient lacks will-power and self-confidence, and is bitterly ashamed of himself for being the reverse of what he was before. He is full of conflict, and cannot give plain and straightforward answers. His civilized nature is at war with his primitive instinct - especially is this so in the case of women, who often have or choose to repress many of their own wishes and ambitions.

Symbolism, too, plays a large part in the mental life of the patient, and many cultured and reserved people, when they are insane, say and do things which only a cultured and able attendant would understand. Food may, to a patient, represent life, or money ; and it is not always easy to tell what a patient means ; but once the symbolism is grasped by the mental expert, he will be able to reassure the patient, and change the current of his thoughts. In any case, he is bound to be morbid and very hypersensitive. Feeling inferior, he may develop a complex by which the instinct of self-preservation may, for example, be perverted temporarily, and so on.

The subject is, of course, one of vast interest ; and as I stated here before, I have seen no cruelty in an asylum, save the legal one which denies a patient a chance to see or write to a friend, and leaves him at the mercy of one petitioner -usually the relative who rushed to have him put away, and who may be a stranger to the patient in everything but blood. I have had happy days in an asylum, and I think the world of my nurses, all of whom respected my reserves, and showed a human rather than professional interest in me, and who showed all their patients the respect and devotion due to the sick. And it is only this human interest which will obtain the response of a patient, for very often the "clever" nurse will make erroneous deductions from sick symptoms, since pathology is a very intricate subject indeed-even to the expert pathologist.

At least, I hope that he thinks so.

J. S. C.

\section{THE TREATMENT OF RATE-AIDED PATIENTS AS VOLUNTARIES IN} THE MENTAL HOSPITALS OF SCOTLAND.

THE following extracts from a memorial addressed to the Secretary of State for Scotland by the Board of Direction of the Crichton Royal Institution are of importance and general interest :

"The Institution is the only mental hospital in the country which publishes annual statistics of the results of treatment of the voluntaries, for purposes of comparison with those relating to the certificated patients, and this fact, and the foregoing data, as to the size and nature of its population, indicate that the Institution is specially in a position to furnish pertinent and important statistical information not otherwise available.

"The following tabular statement shows the results of treatment at the Institution for the 17 years 1908 to 1924 inclusive. (N.B. - The cases admitted and the cases discharged improved or unimproved include transfers respectively from and to other mental hospitals) :

LXXI. 